\title{
Review of the use of resource use instruments based on patient recall in relation to other methods of resource use estimation
}

\author{
Colin Ridyard*, Dyfrig Hughes \\ From 2nd Clinical Trials Methodology Conference: Methodology Matters \\ Edinburgh, UK. 18-19 November 2013
}

\section{Background}

We conducted a review of articles citing trial-related resource use measures catalogued in the Database of Instruments for Resource Use Measurement (http:// www.DIRUM.org). The aims were to assess: (i) how the instruments were used in practice; (ii) which items of resource use were most frequently measured using patient-recall; and (iii) how estimates compared if more than one method of data collection was used for the same resource items

\section{Methods}

Articles citing references to measures were identified using Google Scholar, ISI Web of Science and Scopus. These were reviewed and screened according to inclusion criteria. Data were extracted on: the method of administration, resources measured, rates of return and the nature of the other methods of resource use measurement.

\section{Results}

Nearly all citing articles (143/146) used an instrument derived from Beecham and Knapp's Client Service Receipt Inventory or a variation thereof (81/143). Most measures relied on patient- or proxy-recall $(126 / 146)$ generally administered during researcher interviews. Use of primary and secondary care was the most widely reported items of resource use (136/146). Twelve studies compared more than one method of data collection for the same resource items and 8/12 showed good correlation between medical records and patient/carer recall or at least indicated one could routinely validate the other. No single administration method was deemed superior.

Bangor University, Bangor, Gwynedd, UK

\section{Conclusion}

Patient interviews are the most common method of questionnaire administration but studies lack clarity on how they are conducted. Results indicate good precision and accuracy in recall questionnaire use; however, concerns about recall bias still exist.

Published: 29 November 2013

doi:10.1186/1745-6215-14-S1-022

Cite this article as: Ridyard and Hughes: Review of the use of resource use instruments based on patient recall in relation to other methods of resource use estimation. Trials 2013 14(Suppl 1):O22.
Submit your next manuscript to BioMed Central and take full advantage of:

- Convenient online submission

- Thorough peer review

- No space constraints or color figure charges

- Immediate publication on acceptance

- Inclusion in PubMed, CAS, Scopus and Google Scholar

- Research which is freely available for redistribution
() Bïomed Central 